\title{
Mycorrhizal Fungi were More Effective than Zeolites in Increasing the Growth of Non-Irrigated Young Olive Trees
}

\author{
João I. Lopes ${ }^{1}$, Margarida Arrobas ${ }^{2}$, Cátia Brito ${ }^{3}{ }^{\circledR}$, Alexandre Gonçalves ${ }^{2,3,4}$, \\ Ermelinda Silva ${ }^{3}\left(\mathbb{D}\right.$, Sandra Martins ${ }^{3}$, Soraia Raimundo ${ }^{2}$, Manuel Ângelo Rodrigues ${ }^{2} \mathbb{D}$ and \\ Carlos M. Correia ${ }^{3, *(1)}$ \\ 1 Direção Regional de Agricultura e Pescas do Norte, 5370-347 Mirandela, Portugal; \\ joao.lopes@drapnorte.gov.pt \\ 2 Centro de Investigação de Montanha (CIMO), Instituto Politécnico de Bragança, 5300-253 Bragança, \\ Portugal; marrobas@ipb.pt (M.A.); agoncalves@morecolab.pt (A.G.); soraia-raimundo@live.com.pt (S.R.); \\ angelor@ipb.pt (M.Â.R.) \\ 3 Centre for the Research and Technology of Agro-Environmental and Biological Sciences (CITAB), \\ University of Trás-os-Montes e Alto Douro, 5000-801 Vila Real, Portugal; cvqbrito@utad.pt (C.B.); \\ emsilva@utad.pt (E.S.); scpmartins@utad.pt (S.M.) \\ 4 Collaborative Laboratory Mountains of Research (MORE), Brigantia Ecopark, 5300-358 Bragança, Portugal \\ * Correspondence: ccorreia@utad.pt
}

Received: 26 November 2020; Accepted: 16 December 2020; Published: 19 December 2020

\begin{abstract}
Four soil treatments, consisting of two commercial mycorrhizal fungi, one zeolite and an untreated control, were arranged in a factorial design with two foliar fertilization treatments, a foliar spray and a control to study the effects of commercial mycorrhizal fungi and zeolites on the growth of young, rainfed olive trees planted in very acidic soil. The concentrations in the plant tissues of most of essential nutrients, particularly nitrogen $(\mathrm{N})$, phosphorus $(\mathrm{P})$, potassium $(\mathrm{K})$ and boron $(\mathrm{B})$, did not significantly change with the soil treatments, whereas leaf $\mathrm{N}$ and $\mathrm{B}$ concentrations significantly increased with foliar fertilization. Leaf calcium $(\mathrm{Ca})$ and magnesium $(\mathrm{Mg})$ levels were found to be much lower than their respective sufficiency ranges and increased with soil amendments, also giving positive outcomes for plant water status, photosynthetic activity and assimilation area. Ultimately, the mycorrhizal fungi increased the growth of the young trees, whereas the effect of zeolites was much smaller and not significantly different to the control. Thus, it seems that in this very acidic soil and under rainfed conditions, the major benefits for plants from the application of mycorrhizal fungi and zeolites were the alleviation of drought stress and tissue $\mathrm{Ca}$ and $\mathrm{Mg}$ disorders.
\end{abstract}

Keywords: Olea europaea; soil conditioners; biostimulants; biofertilizers; plant growth

\section{Introduction}

As has been called for by society, the scientific community seeks to help farmers in the search for ever more sustainable methods of soil management. It is agreed that the use of chemical fertilizers should be reduced in order to avoid environmental contamination. Many other fertilizing materials, however, such as soil conditioners and biostimulants, can be used as a means of reducing the use of chemical fertilizers while maintaining or increasing agricultural productivity [1-3].

Natural zeolites are hydrated crystalline aluminosilicates of alkali and alkaline earth metals, among which clinoptilolite is apparently the most abundant [4,5]. Zeolites have high cation exchange capacities (CECs) and high void volumes. These unique features facilitate the movement of ions to and from the mineral structure, increasing nutrient sorption and improving soil moisture conditions [6]. 
The negative charges of the clinoptilolite zeolite can retain nutrients which can be released in a timely manner, increasing nutrient use efficiency $[7,8]$ while reducing nutrient losses from soils by leaching [9] or ammonia volatilization [8]. Studies have also shown that zeolites can increase water availability to plants $[4,6]$ and ultimately improve crop yield [10].

Among biostimulants, in addition to those containing $\mathrm{N}_{2}$-fixing microorganisms, which are the most studied and widely used in agriculture [11], there are others of increasing interest which contain mycorrhizal fungi. It is remarkable that $\sim 90 \%$ of all terrestrial plants, including cultivated species, establish mutualistic associations with mycorrhizal fungi $[12,13]$. Mycorrhizal fungi develop extensive hyphal networks in the soil, which are able to significantly increase the uptake of nutrients and water, thereby benefiting the host plant $[13,14]$. Phosphorus $(\mathrm{P})$ is the nutrient that is most likely to be supplied by mycorrhizal fungi, especially in P-limited soils [15-17]. However, it has also been proven that under particular conditions, plants can benefit from the increased uptake of the majority of essential nutrients [18-20]. The mycorrhizal associations may also increase a plant's tolerance to drought $[21,22]$ or to heavy metals in the soil $[23,24]$. They may also help plants cope with biotic stresses [25]. Additional non-nutritional effects have also been reported, namely the role of mycorrhizal hyphae on carbon (C) input into soil organic matter [26,27].

Despite the potential for using soil conditioners and biostimulants, an important step that needs to be further studied is how, and under what conditions, agriculture should take advantage of the effective use of commercial products [28]. Should farmers adopt the widespread use of these materials, or should they only be used in agroecological environments where previous studies have shown positive results? It is necessary to take into account that soil conditioners and biostimulants have a cost that producers have to bear. Mycorrhizal associations, on the other hand, are ubiquitous in nature and are present in most agricultural ecosystems $[12,13]$. This means that in many situations, the use of commercial mycorrhizal fungi is being left redundant through non-use.

In vast areas of the Mediterranean basin, where irrigation water is not available, the olive tree is the only cash crop that is capable of mitigating the depopulation of rural areas, due to its adaptation to both drought stress [29-31] and low-fertility soils [32,33]. However, in such harsh conditions, it is particularly important to have tools that can help plants to maintain growth and yield at a profitable level. From a theoretical point of view, soil conditioners and biostimulants are tools that can help the plants cope with such environmental constraints. In the region, zeolites have been consistently advertised by vendors as having high potential as a soil conditioner to promote plant growth, as well as plant biostimulants containing mycorrhizal fungi. Regarding biostimulants, of the commercial products available on the market, the options selected for this study were two that had a greater diversity of fungi. As none of the products were obtained from local microbiology, perhaps more biodiverse products may have had greater versatility in dealing with local ecological conditions. Thus, the working hypothesis is that zeolites or commercial mycorrhizal fungi applied upon the planting of a rainfed olive orchard can improve the nutritional status and performance of the plants in comparison with those grown under an untreated control.

\section{Materials and Methods}

\subsection{Study Site}

An on-farm field trial was established in Passos $(41.451879,-7.241243)$ in the municipality of Mirandela in northeast Portugal. Young rooted Cobrançosa olive trees $\sim 60 \mathrm{~cm}$ in height were planted on March 15, 2017. The distance between rows and plants within the rows was $7 \times 7 \mathrm{~m}$, the planting density (204 trees ha ${ }^{-1}$ ) commonly used in managed rainfed olive orchards in the region. The climate of the region was of a Mediterranean type, with an average annual air temperature of $14.3^{\circ} \mathrm{C}$ and a cumulative annual rainfall of $509 \mathrm{~mm}$. Meteorological data recorded during the experimental period is presented in Figure 1. The soil of the orchard was of the Cambisol group, being loamy sand-textured 
(78.4\% sand, $15.4 \%$ silt and $6.2 \%$ clay) and formed in a bed rock of schist. Other selected soil properties at the beginning of the field trial are presented in Table 1.

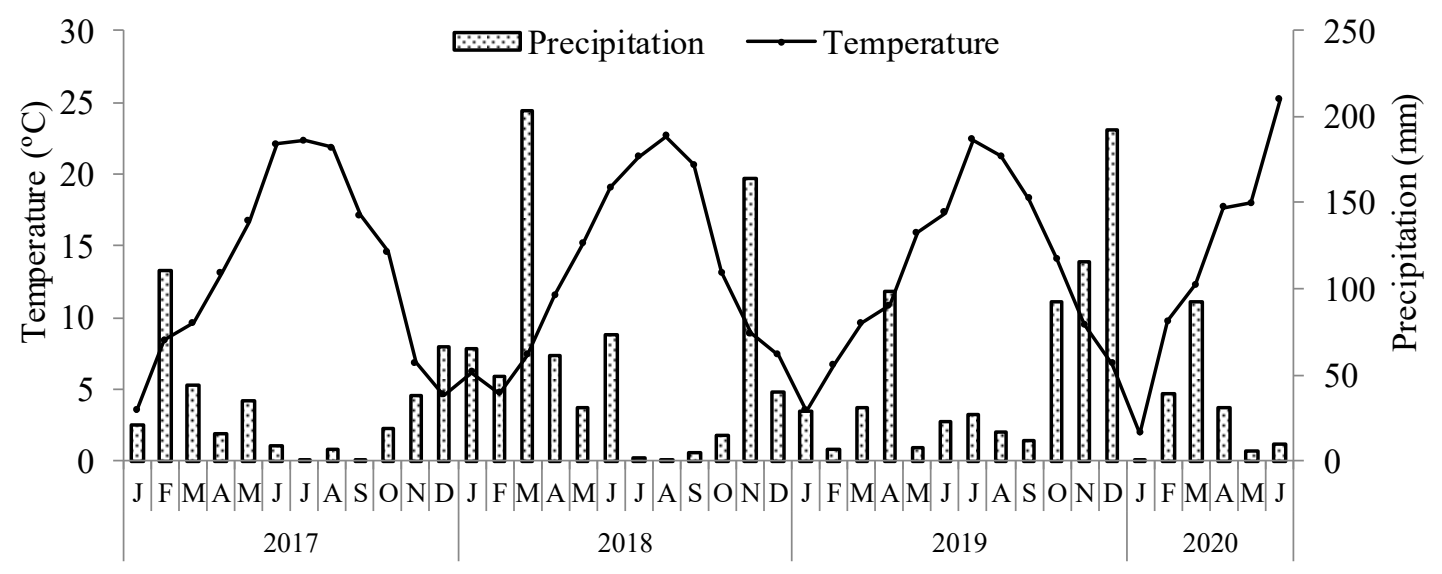

Figure 1. Average monthly air temperature and precipitation recorded during the experimental period in the weather station at Paradela, close to the experimental plot.

Table 1. Selected soil properties (average \pm standard deviation) from samples taken at depths of 0-30 $\mathrm{cm}$ at the beginning of the field trial.

\begin{tabular}{|c|c|c|c|}
\hline \multicolumn{2}{|c|}{ Soil Properties } & \multicolumn{2}{|c|}{ Soil Properties (cont.) } \\
\hline${ }^{1}$ Organic carbon $\left(\mathrm{g} \mathrm{kg}^{-1}\right)$ & $4.5 \pm 0.9$ & ${ }^{5}$ Extract. $\mathrm{Zn}\left(\mathrm{mg} \mathrm{kg}^{-1}\right)$ & $0.5 \pm 0.12$ \\
\hline${ }^{2} \mathrm{pH}\left(\mathrm{H}_{2} \mathrm{O}\right)$ & $4.5 \pm 0.12$ & ${ }^{5}$ Extract. $\mathrm{Cu}\left(\mathrm{mg} \mathrm{kg}^{-1}\right)$ & $0.9 \pm 0.47$ \\
\hline $2 \mathrm{pH}(\mathrm{KCl})$ & $3.6 \pm 0.06$ & ${ }^{6}$ Exchang. Ca $\left(\mathrm{cmol}_{\mathrm{C}} \mathrm{kg}^{-1}\right)$ & $4.8 \pm 0.96$ \\
\hline${ }^{3}$ Extract. $\mathrm{P}\left(\mathrm{mg} \mathrm{P}_{2} \mathrm{O}_{5} \mathrm{~kg}^{-1}\right)$ & $32.0 \pm 4.3$ & ${ }^{6}$ Exchang. $\mathrm{Mg}\left(\mathrm{cmol}_{\mathrm{c}} \mathrm{kg}^{-1}\right)$ & $1.1 \pm 0.28$ \\
\hline${ }^{3}$ Extract. $\mathrm{K}\left(\mathrm{mg} \mathrm{K}_{2} \mathrm{O} \mathrm{kg}^{-1}\right)$ & $81.5 \pm 15.2$ & ${ }^{6}$ Exchang. $\mathrm{K}\left(\mathrm{cmol}_{\mathrm{c}} \mathrm{kg}^{-1}\right)$ & $0.3 \pm 0.04$ \\
\hline${ }^{4}$ Extract. B $\left(\mathrm{mg} \mathrm{kg}^{-1}\right)$ & $0.5 \pm 0.06$ & ${ }^{6}$ Exchang. $\mathrm{Na}\left(\mathrm{cmol}_{\mathrm{C}} \mathrm{kg}^{-1}\right)$ & $0.2 \pm 0.01$ \\
\hline${ }^{5}$ Extract. $\mathrm{Fe}\left(\mathrm{mg} \mathrm{kg}^{-1}\right)$ & $36.2 \pm 3.28$ & ${ }^{7}$ Exchang. acidity $\left(\mathrm{cmol}_{\mathrm{c}} \mathrm{kg}^{-1}\right)$ & $0.1 \pm 0.08$ \\
\hline${ }^{5}$ Extract. $\mathrm{Mn}\left(\mathrm{mg} \mathrm{kg}^{-1}\right)$ & $76.1 \pm 15.50$ & $\mathrm{CEC}\left(\mathrm{cmol}_{\mathrm{C}} \mathrm{kg}^{-1}\right)$ & $6.4 \pm 1.24$ \\
\hline
\end{tabular}

${ }^{1}$ Wet digestion (Walkley-Black); ${ }^{2}$ potentiometry; ${ }^{3}$ ammonium lactate; ${ }^{4}$ hot water, azomethine- $\mathrm{H} ;{ }^{5}$ ammonium acetate and EDTA (ethylenediaminetetraacetic acid); ${ }^{6}$ ammonium acetate $;{ }^{7}$ potassium chloride.

\subsection{Experimental Design and Management}

The experiment was arranged as a factorial design with four soil treatments (zeolites, two biostimulants containing propagules of mycorrhizal fungi and a non-treated control) and two foliar fertilizing treatments (foliar spray and an untreated control), with three replications and three plants per replication.

The zeolite used in this experiment was a natural aluminosilicate of alkali and alkaline earth metals, applied at a rate of $120 \mathrm{~g} \mathrm{plant}^{-1}$. The main properties of the zeolite are presented in Table 2. One of the commercial biostimulants (myco1) contained the propagules (spores, mycelium and colonized root fragments) of five different species of arbuscular mycorrhizal (AM) fungi (Rhizophagus irregularis, Funneliformis mosseae, F. geosporum, F. coronatum and Claroideoglomus claroideum), where a natural zeolite acts as a carrier of fungi (Offyougrow Standard ${ }^{\circledR}$, Symbiom s.r.o., Czech Republic). The second biostimulant (myco2) contained the propagules of nine species of ectomycorrhizal fungi and nine species of AM fungi. The ectomycorrhizal fungi were Pisolithus tinctorius, Rhizopogon spp. (four species), Scleroderma spp. (two species) and Laccaria spp. (two species). Regarding the AM fungi, seven were of the genus Glomus, and the other two species were Rhizophagus irregularis and Paraglomus brasilianum (Roots ${ }^{\circledR}$, M-Roots, 3:3:3, LebanonTurf). The biostimulants myco1 and myco2 were applied at the rates recommended by the vendors, 120 and $15 \mathrm{~g} \mathrm{plant}^{-1}$, respectively. In this first study in the region with these biostimulants, and taking into account that they were commercial products prepared to be used by farmers, it was decided to use the rates recommended by the vendors, which 
were the rates that farmers would apply. The commercial product myco2 was enriched in NPK by the manufacturer $\left(3 \% \mathrm{~N}, 3 \% \mathrm{P}_{2} \mathrm{O}_{5}\right.$, and $\left.3 \% \mathrm{~K}_{2} \mathrm{O}\right)$. Taking this into account, all the other treatments, including the control treatment, received this small rate of $\mathrm{N}, \mathrm{P}$ and $\mathrm{K}$ as a compound NPK $(10 \%$ $\mathrm{N}, 10 \% \mathrm{P}_{2} \mathrm{O}_{5}$ and $10 \% \mathrm{~K}_{2} \mathrm{O}$ ) fertilizer to isolate the effect of microorganisms. Both biostimulants were homogenously spread in the burrows opened to plant the young trees to easily reach the root system. Olive planting and the application of zeolites and biostimulants were performed on 15 March 2017. As foliar sprays, two commercial products were applied twice a year, first on March 15 and 15 September 2018, and again on 15 March and 15 September 2019. A liquid NPK $\left(w / w ; 12 \% \mathrm{~N}, 4 \% \mathrm{P}_{2} \mathrm{O}_{5}\right.$, $\left.6 \% \mathrm{~K}_{2} \mathrm{O}\right)$ fertilizer enriched with micronutrients $(0.02 \% \mathrm{~B}, 0.01 \% \mathrm{Cu}$-EDTA, $0.02 \%$ Fe-EDTA, $0.01 \%$ Mn-EDTA, $0.005 \%$ Zn-EDTA and $0.005 \% \mathrm{Mo}$ ) was used. As dicot species display chronic B deficiency in the region [34,35], foliar fertilization was supplemented with the application of a liquid fertilizer containing B in ethanolamine form $(11 \% \mathrm{~B}, w / w)$.

Table 2. Selected properties of zeolites used in this experiment (data provided by the manufacturer).

\begin{tabular}{|c|c|c|c|}
\hline \multicolumn{4}{|c|}{ General Formula: $\left(\mathrm{Ca}, \mathrm{K}_{2}, \mathrm{Na}_{2}, \mathrm{Mg}\right)_{4} \mathrm{Al}_{8} \mathrm{Si}_{40} \mathrm{O} 96.24 \mathrm{H}_{2} \mathrm{O}$} \\
\hline \multicolumn{2}{|c|}{ Mineral composition (\%) } & \multicolumn{2}{|c|}{ Chemical composition (\%) } \\
\hline Clinoptilolite & 84 & $\mathrm{SiO}_{2}$ & $65.0-71.3$ \\
\hline Cristobalite & 8 & $\mathrm{Al}_{2} \mathrm{O}_{3}$ & $11.5-13.1$ \\
\hline Clay mica & 4 & $\mathrm{CaO}$ & $2.7-5.2$ \\
\hline Plagioclase & $3-4$ & $\mathrm{~K}_{2} \mathrm{O}$ & $2.2-3.4$ \\
\hline Rutile & $0.1-0.3$ & $\mathrm{FeO}_{3}$ & $0.7-1.9$ \\
\hline \multirow[t]{2}{*}{ Quartz } & Traces & $\mathrm{MgO}$ & $0.6-1.2$ \\
\hline & & $\mathrm{Na}_{2} \mathrm{O}$ & $0.2-0.3$ \\
\hline \multicolumn{2}{|c|}{ Ion exchange $\left(\mathrm{mol} \mathrm{kg}^{-1}\right)$} & \multicolumn{2}{|c|}{ Physical and mechanical properties } \\
\hline $\mathrm{Ca}^{2+}$ & $0.64-0.08$ & Volume density & $1600-1800 \mathrm{~kg} \mathrm{~m}^{-3}$ \\
\hline $\mathrm{K}^{+}$ & $0.22-0.45$ & Porosity & $24-32 \%$ \\
\hline $\mathrm{Mg}^{2+}$ & $0.06-0.19$ & Diameter of pores & $0.4 \mathrm{~nm}$ \\
\hline $\mathrm{Na}^{+}$ & $0.01-0.19$ & Specific surface & $30-60 \mathrm{~m}^{2} \mathrm{~g}^{-1}$ \\
\hline CEC & $1.2-1.59$ & & \\
\hline
\end{tabular}

\subsection{Field Determinations}

The young plants were subjected to a light pruning twice a year, and the pruning wood was weighed fresh per experimental unit (three plants). Random subsamples were taken and separated into stems and leaves and weighed again fresh. The subsamples of the different tissues were thereafter sent to the laboratory, oven-dried at $70^{\circ} \mathrm{C}$ and weighed dry. This procedure allowed us to use the pruning wood and the concentration of mineral nutrients in the pruning wood as the results of this experiment.

The plant height and stem diameter at $20 \mathrm{~cm}$ above ground were also measured three and two times during the experimental period, respectively. The dates of the plant height measurements were 14 January 2018, 15 April 2019 and 15 April 2020. The stem diameter was measured only on the second and third dates.

Leaf gas exchange measurements were performed four times during the experiment on cloudless summer days (July and September of 2018 and 2019), using a portable infrared gas analyzer (LCpro+, ADC, Hoddesdon, UK) operating in open mode. Atmospheric conditions consisted of a photosynthetic photon flux density above $1500 \mu \mathrm{mol} \mathrm{m}-2 \mathrm{~s}^{-1}$ and an air temperature between $32^{\circ} \mathrm{C}$ and $35^{\circ} \mathrm{C}$. The net photosynthetic rate $\left(\mathrm{A}, \mu \mathrm{mol} \mathrm{CO} \mathrm{CO}^{-2} \mathrm{~s}^{-1}\right)$, stomatal conductance $\left(\mathrm{g}_{\mathrm{s}}, \mathrm{mmol} \mathrm{H}_{2} \mathrm{O} \mathrm{m}^{-2} \mathrm{~s}^{-1}\right)$ and ratio of intercellular to atmospheric $\mathrm{CO}_{2}$ concentration $\left(\mathrm{C}_{\mathrm{i}} / \mathrm{C}_{\mathrm{a}}\right)$ were estimated using the equations developed by Von Caemmerer and Farquhar [36]. Intrinsic water use efficiency was calculated as the ratio of $\mathrm{A} / \mathrm{g}_{\mathrm{s}}\left(\mu \mathrm{mol} \mathrm{mol}^{-1}\right)$. 


\subsection{Laboratory Analysis}

Soil samples were oven-dried at $40{ }^{\circ} \mathrm{C}$ and sieved ( $2 \mathrm{~mm}$ mesh) before being submitted to the following analytical determinations: (1) $\mathrm{pH}\left(\mathrm{H}_{2} \mathrm{O}\right.$ and $\left.\mathrm{KCl}\right)$ (potentiometry); (2) organic $\mathrm{C}$ (Walkley-Black method); (3) cation exchange capacity (ammonium acetate, $\mathrm{pH} 7.0$ ); (4) extractable $\mathrm{P}$ and $\mathrm{K}$ (ammonium lactate solution, $\mathrm{pH}$ 3.7); (5) extractable B (hot water and azomethine-H); (6) extractable $\mathrm{Fe}, \mathrm{Mn}, \mathrm{Zn}$ and $\mathrm{Cu}$ (ammonium acetate and EDTA, determined by atomic absorption spectrometry); and (7) soil separation (by the Robinson pipette method). Methods 1-3 and 6-7 are fully described by Van Reeuwijk [37], method 4 by Balbino [38] and method 5 by Jones [39].

Plant tissues were oven-dried at $70{ }^{\circ} \mathrm{C}$ and ground. Elemental analyses of all the tissues (leaves and stems) were performed by the Kjeldahl $(\mathrm{N})$, colorimetry (B and $\mathrm{P}$ ), and atomic absorption spectrophotometry ( $\mathrm{K}, \mathrm{Ca}, \mathrm{Mg}, \mathrm{Fe}, \mathrm{Mn}, \mathrm{Cu}$ and $\mathrm{Zn}$ ) methods [40] after tissue samples were digested with nitric acid in a microwave.

\subsection{Data Analysis}

Data was first tested for the normality and homogeneity of variances using the Shapiro-Wilk test and Bartlett's test, respectively. The comparison of the effect of the treatments was performed by two-way ANOVA for variables taken once during the experimental period. In situations where the variables were taken multiple times (nutrient concentration in plant tissues), three-way ANOVA was performed, considering the sampling date a third experimental factor. When significant differences were found $(\alpha<0.05)$, the means were separated by the multiple range Tukey honestly significant difference (HSD) test $(\alpha=0.05)$.

\section{Results}

\subsection{Plant Growth}

The pruning wood varied significantly with the soil and foliar treatments (Figure 2). Significant differences in leaf, stem and total prunings between soil treatments were recorded for most of the pruning events and the total pruning wood. Myco1 gave significantly higher values than the control and zeolite treatments. Myco2 gave higher average values than the control and zeolite treatments, but the differences were not statistically significant. Foliar sprays also increased the leaf, stem and total prunings significantly in comparison with the untreated control, at least when comparing the sum of the prunings of the four pruning events.

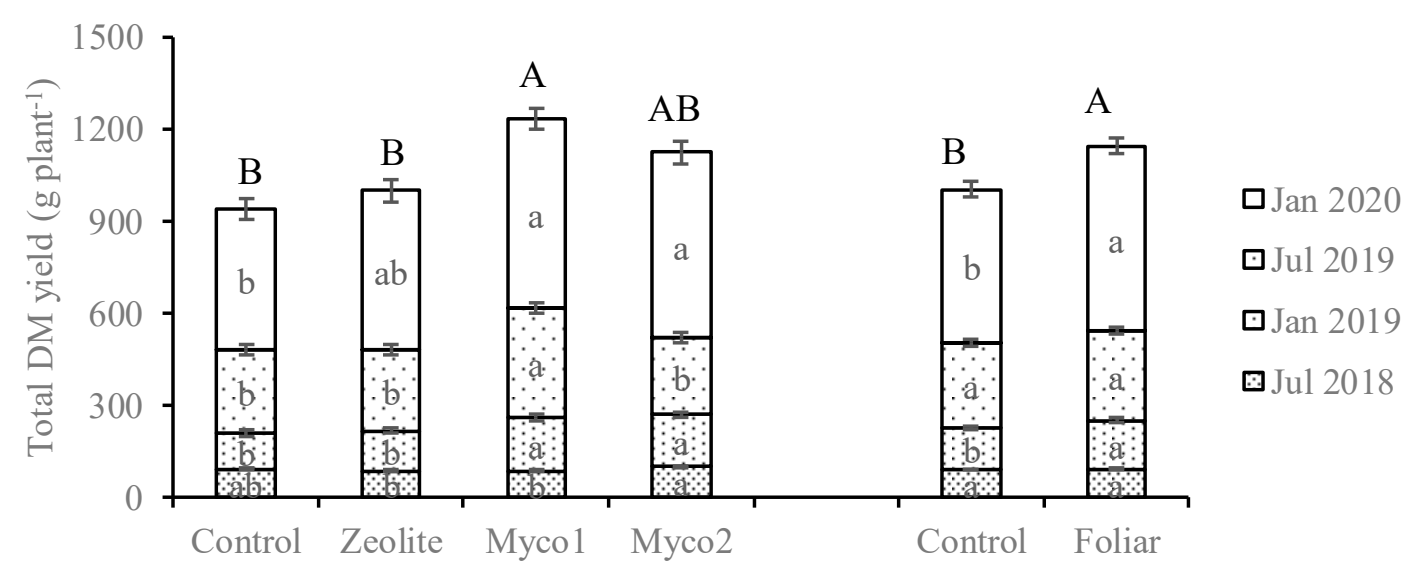

Figure 2. Total dry matter (DM) of prunings after four consecutive pruning events in July (Jul) 2018 and 2019 and January (Jan) 2019 and 2020. Within the soil and foliar fertilization factors, and for each pruning (lowercase letters) or the sum of the four pruning events (uppercase letters), the means followed by the same letter were not significantly different by the Tukey HSD test $(\alpha=0.05)$. The vertical bars are the standard errors. 
The increase in plant height was not significantly different between soil treatments (Figure 3). The plants grew on average between 125 and $135 \mathrm{~cm}$ in height during the experimental period. The foliar sprays, however, significantly increased the plant height in comparison with the unfertilized control. At the end of the experimental period, an increase in height of 121.8 and $137.3 \mathrm{~cm}$ was recorded in the control and foliar fertilizer treatments, respectively.

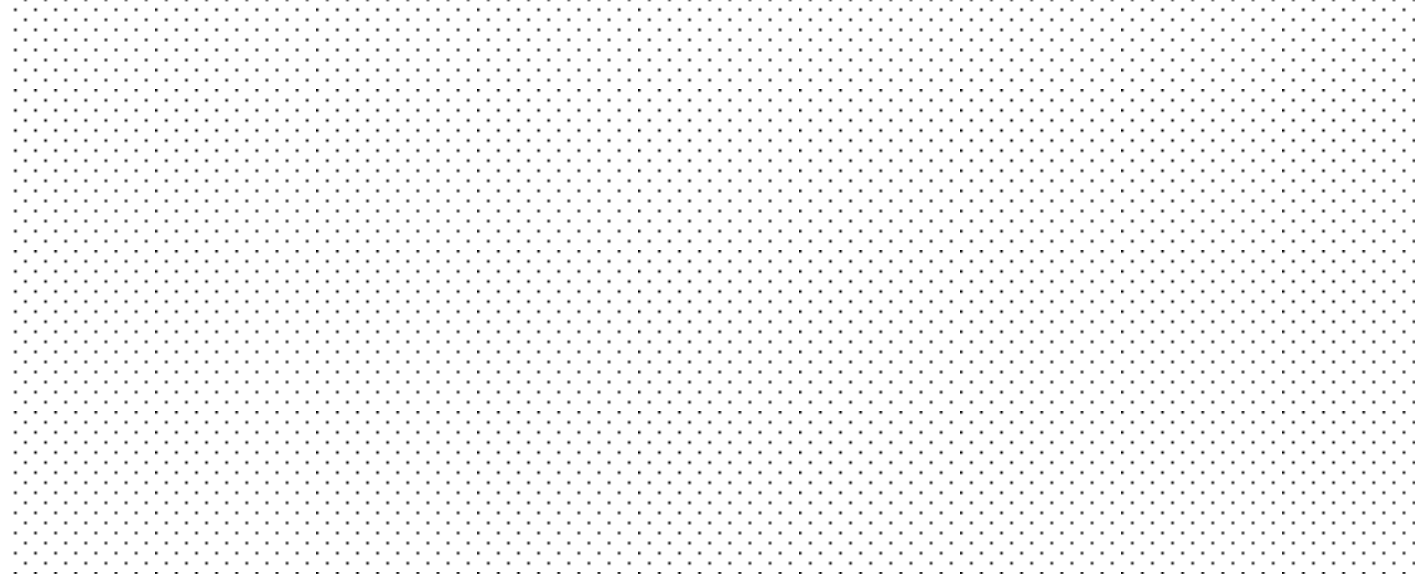

Figure 3. Variation $(\Delta)$ in plant height growth from March 2017, the date of planting, to the end of the experimental period. Within the soil and foliar fertilization factors, and for each measuring period (lowercase letters) or total plant height increase (uppercase letters), the means followed the same letter were not significantly different by the Tukey HSD test $(\alpha=0.05)$. The vertical bars are the standard errors.

The stem diameters of the young olive plants did not vary significantly between soil treatments until April 2019 (Figure 4). However, in the last measurement in April 2020, myco2 gave significantly higher values than the untreated control. Foliar fertilization gave a significant increase in stem diameter from the first measurement to the last in comparison with the unfertilized control.

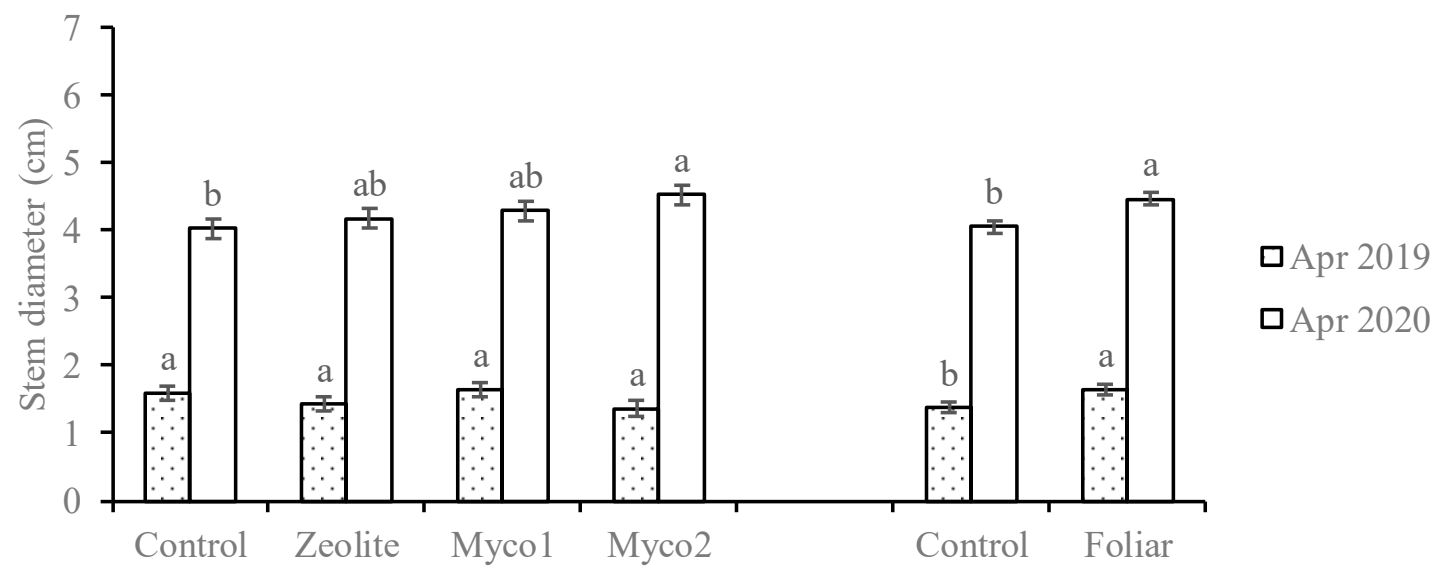

Figure 4. Stem diameter at $20 \mathrm{~cm}$ above ground, measured in April 2019 and April 2020. Within soil and foliar fertilization factors, the means followed by the same letter were not significantly different by the Tukey HSD test $(\alpha=0.05)$. The vertical bars are the standard errors.

\subsection{Nutrient Concentration in Plant Tissues}

The $\mathrm{N}$ concentration in the leaves decreased significantly over the experimental period (Figure 5). The average values dropped from $17.0 \mathrm{~g} \mathrm{~kg}^{-1}$ in July 2018 to $11.7 \mathrm{~g} \mathrm{~kg}^{-1}$ in January 2020. Soil treatments did not influence the $\mathrm{N}$ nutritional status of the plants. The average values were found to be between 14.6 and $15.4 \mathrm{~g} \mathrm{~kg}^{-1}$. Foliar spray use significantly increased the leaf $\mathrm{N}$ concentration in comparison 
with the untreated control. Leaf $P$ increased significantly over the experimental period. The higher average values were found in the last sampling date in January 2020. The leaf P concentration did not vary with soil or foliar treatments. The average values were found to be between 1.1 and $1.2 \mathrm{~g} \mathrm{~kg}^{-1}$. Leaf $\mathrm{K}$ levels varied significantly with the sampling dates. Summer sampling gave significantly higher values than winter sampling. Soil treatments or foliar sprays did not have a significant effect on the leaf $\mathrm{K}$ concentrations. The average values were found to be between 7.3 and $7.7 \mathrm{~g} \mathrm{~kg}^{-1}$.
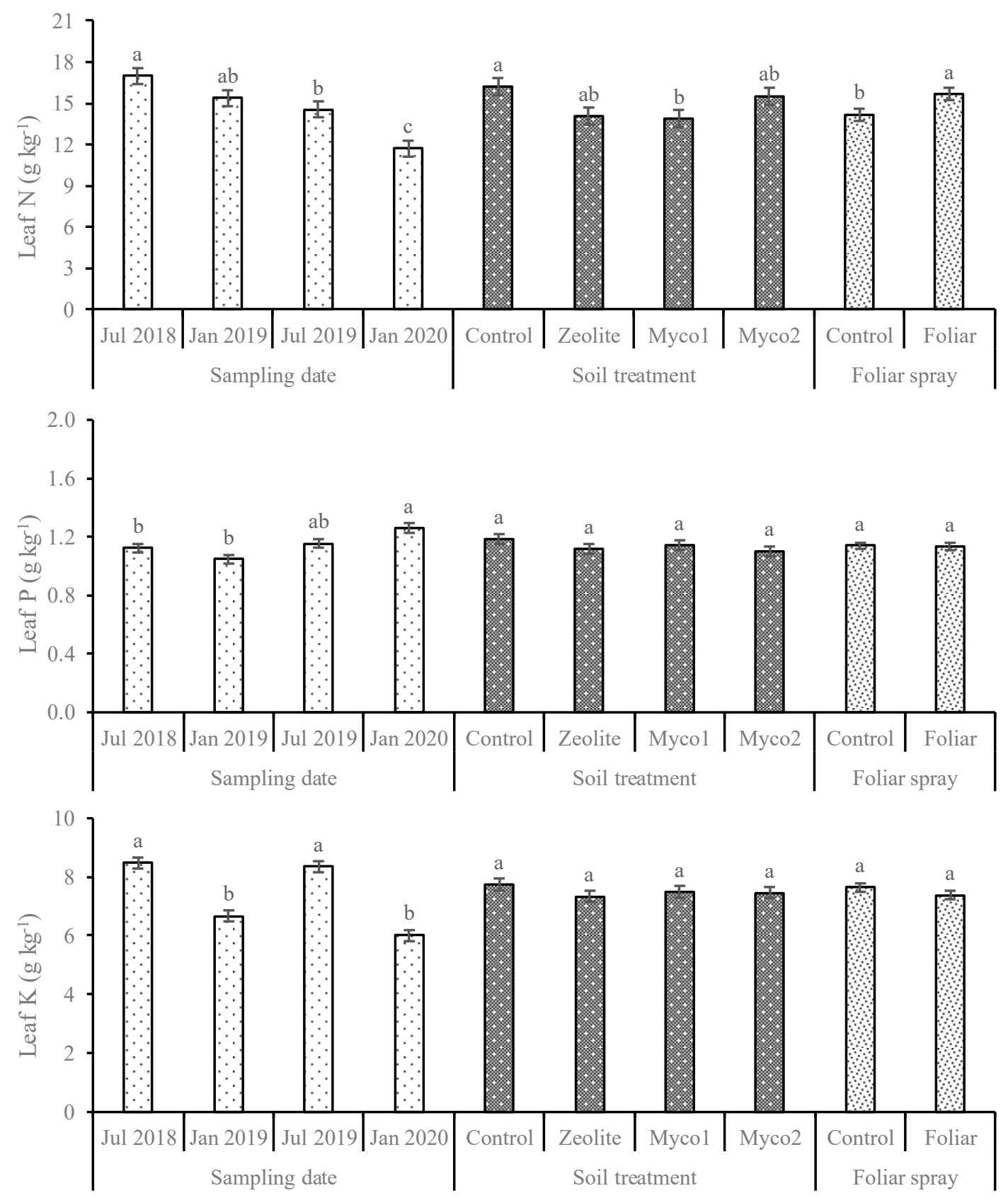

Figure 5. Leaf nitrogen $(\mathrm{N})$, phosphorus $(\mathrm{P})$ and potassium $(\mathrm{K})$ concentrations in response to the sampling date, soil treatment and foliar spray. Within the sampling date, soil treatment or foliar spray, the means followed by the same letter were not significantly different by the Tukey HSD test $(\alpha=0.05)$. The vertical bars are the standard errors.

The leaf Ca concentration varied significantly with the sampling date (Figure 6). The average values in the two last samplings were significantly lower than in the previous ones. The plants with the 
zeolite, myco1 and myco2 treatments gave significantly higher values than those of the untreated control. Foliar treatment did not significantly influence the leaf Ca concentration. Taking all the treatments into account, the average leaf Ca levels varied between 2.4 and $3.4 \mathrm{mg} \mathrm{kg}^{-1}$. The concentration of $\mathrm{Mg}$ in the leaves also varied significantly with the sampling date. The first sampling in July 2018 gave lower values. Leaf $\mathrm{Mg}$ levels varied significantly with the soil treatment. The plants with the myco2 treatment displayed significantly higher values than that of the control. Foliar sprays did not significantly influence the leaf $\mathrm{Mg}$ levels. The average $\mathrm{Mg}$ concentrations varied from 0.9 to $1.2 \mathrm{~g} \mathrm{~kg}^{-1}$. Leaf $B$ levels varied significantly with the sampling date. The higher and lower average values were found, respectively, in the first and second sampling dates. Soil treatments did not significantly change the leaf B levels. Foliar sprays gave significantly higher B values than the untreated control. Overall average values varied from 12.3 to $14.1 \mathrm{mg} \mathrm{kg}^{-1}$.
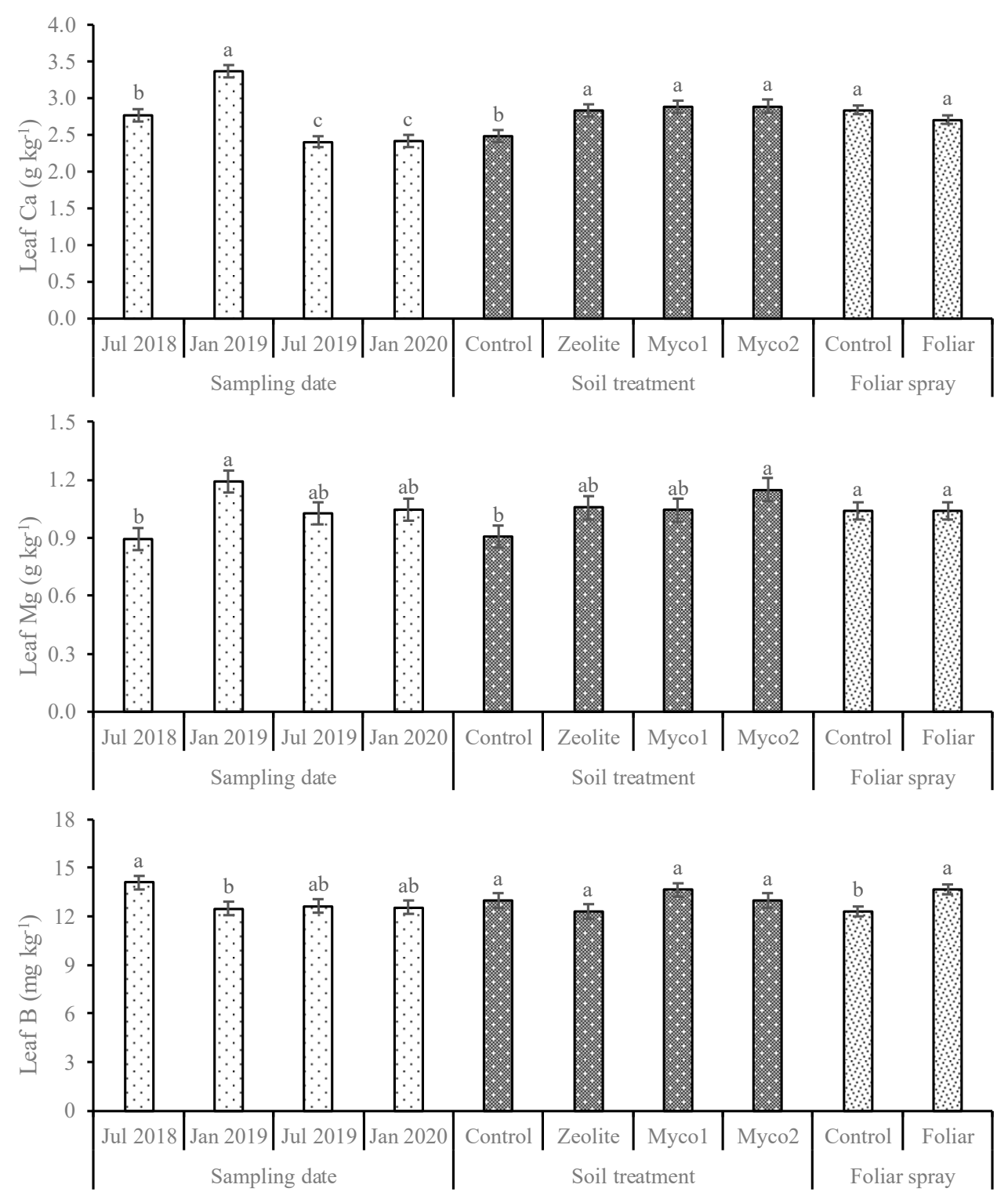

Figure 6. Leaf calcium (Ca), magnesium $(\mathrm{Mg})$ and boron (B) concentrations in response to the sampling date, soil treatment and foliar spray. Within the sampling date, soil treatment or foliar spray, the means followed by the same letter were not significantly different by the Tukey HSD test $(\alpha=0.05)$. The vertical bars are the standard errors. 
The leaf concentrations of $\mathrm{Fe}, \mathrm{Mn}, \mathrm{Zn}$ and $\mathrm{Cu}$ varied significantly between sampling dates. However, none of the concentrations of these nutrients varied significantly with soil or leaf treatments (data not shown). The average leaf $\mathrm{Fe}, \mathrm{Mn}, \mathrm{Zn}$ and $\mathrm{Cu}$ levels were found to be in the ranges of $172-227 \mathrm{mg} \mathrm{kg}^{-1}, 77-98 \mathrm{mg} \mathrm{kg}^{-1}, 13-20 \mathrm{mg} \mathrm{kg}^{-1}$ and $13-25 \mathrm{mg} \mathrm{kg}^{-1}$, respectively.

\subsection{Leaf Gas Exchange}

Figure 7 shows the influence of soil and foliar treatments on leaf gas exchange variables over the experimental period. The first evidence of significant differences between treatments was detected in July 2018, where the foliar fertilized plants had a lower $C_{i} / C_{a}$ than the control plants. Later on, in September, the effect of the soil treatments started to manifest, as the myco1 treatment gave a higher $\mathrm{g}_{\mathrm{s}}$ than the control plants, while the zeolite and control treatments presented higher and lower values of $\mathrm{A} / \mathrm{g}_{\mathrm{s}}$ and $\mathrm{C}_{\mathrm{i}} / \mathrm{C}_{\mathrm{a}}$, respectively, than the myco1 and myco2 plants. In addition, a tendency for higher net photosynthetic rates was observed in the plants with myco1 $(P=0.075)$ and zeolite $(P=0.079)$ treatments in comparison with the control treatment. Furthermore, in July 2019, the lower A and $\mathrm{g}_{\mathrm{s}}$ of zeolite, relative to the control and myco2 treatments, stood out, whereas in September 2019, myco1 plants had a higher A than the contro1 and a superior $\mathrm{g}_{\mathrm{s}}$ to all other treatments. Moreover, myco2 had a superior $A / g_{s}$ to the control and myco1 treatments and a lower $C_{i} / C_{a}$. During 2019, foliar fertilization promoted an increase of the $\mathrm{A}$ and $\mathrm{g}_{\mathrm{s}}$, whereas a tendency toward a higher $\mathrm{A} / \mathrm{g}_{\mathrm{s}}(P=0.081)$ was observed in July.

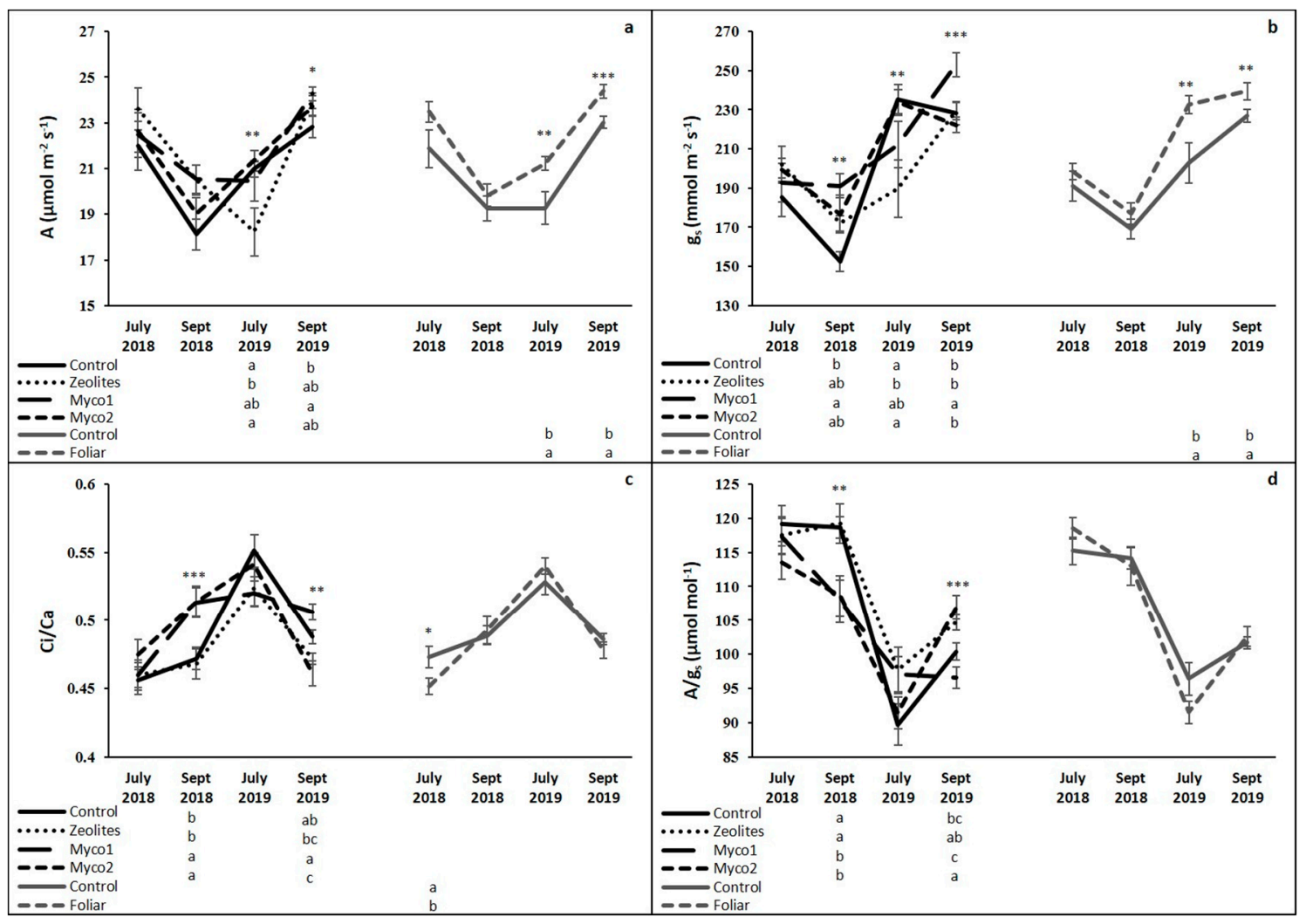

Figure 7. Net photosynthetic rate (a), stomatal conductance to water vapor (b), ratio of intercellular to atmospheric $\mathrm{CO}_{2}$ concentration (c) and intrinsic water use efficiency (d) responses to soil treatment and foliar spray. Within the soil and foliar fertilization factors, the means followed by the same letter were not significantly different by the Tukey HSD test $(\alpha=0.05)$. The vertical bars are the standard errors. Significance: ${ }^{*} p<0.05,{ }^{* *} p<0.01,{ }^{* *} p<0.001$. 


\section{Discussion}

The dry matter of the prunings and the plant stem diameter were higher under the commercial mycorrhizal fungi treatments, in comparison with the control. The effect of the soil treatments on plant height was not significant, perhaps due to the weak apical dominance of the olive tree [41]. Zeolites showed a tendency toward higher average values of pruning wood and stem diameter than the control, but without significant differences. The mycorrhizal-induced biomass enhancement was associated with an increase in the assimilation area, judging by the changes in leaf dry mass removed by pruning and the leaf mass area (LMA) subsamples taken during the last pruning event. In fact, considering that the leaf dry mass reached 212.5, 181.9 and $157.9 \mathrm{~g} \mathrm{plant}^{-1}$ in myco1, myco2 and the control treatment, respectively, and the corresponding LMAs were 214.4, 216.6 and $224.1 \mathrm{~g} \mathrm{~m}^{-2}$, we estimate that the leaf area removed was 99.1 and $84.0 \mathrm{dm}^{2}$ plant $^{-1}$ in the myco1 and myco2 plants, respectively, against $70.5 \mathrm{dm}^{2}$ plant $^{-1}$ in the control treatment. Higher leaf areas and plant biomass accumulations by mycorrhizal fungi treatments have also been previously reported [42]. Meanwhile, higher net photosynthetic rates in mycorrhizal treatments, mainly in myco1, were observed on some occasions, as well as in the study of Chandrasekaran et al. [43], due to the lower stomatal and biochemical limitations, as evidenced by the changes in $\mathrm{g}_{\mathrm{s}}, \mathrm{A} / \mathrm{g}_{\mathrm{s}}$ and $\mathrm{C}_{\mathrm{i}} / \mathrm{C}_{\mathrm{a}}$ data, which also contributed to better plant performance. It should be emphasized that the accumulation of small increases in net photosynthesis over a long period might contribute, to some extent, to a higher leaf area and to a greater pruning dry weight and stem diameter. Interestingly, despite the larger leaf area dimensions, mycorrhizal inoculated plants, mostly myco1, generally had higher stomatal conductance than the control plants, which is a good indicator of better plant water status and growth, especially under mild to moderate drought stress conditions [44]. This response is probably related to the hyphal extensions of mycorrhiza that allow higher hydraulic conductivity [43].

Mycorrhizal fungi and zeolite treatments had a reduced influence on the concentration of the macronutrients $\mathrm{N}, \mathrm{P}$ and $\mathrm{K}$ in the leaves. However, $\mathrm{N}$ levels decreased continuously over the experimental period, having dropped below $15 \mathrm{mg} \mathrm{kg}^{-1}$, the lower limit of the sufficiency range [45]. Sufficiency ranges are established for mature trees, but they can also be used as a guide for the concentration of nutrients in the leaves of young plants [46]. The plots did not receive soil fertilization during the experimental period, and agricultural soils do not usually contain $\mathrm{N}$ in readily available forms to sustain the normal growth of crops [47], especially in soils with such low levels of organic matter (Table 1). Thus, the drop in tissue $\mathrm{N}$ concentrations was the result of the well-known dilution effect [48,49], resulting from the increase in plant biomass and reduced $\mathrm{N}$ uptake. In the case of leaf $\mathrm{P}$ levels, a growing trend was observed over time, but without significant differences between treatments, which may reflect the establishment of symbiotic associations between plants and native microorganisms. It should be noted that the olive tree is the main crop in the region and beneficial microorganisms, particularly ectomycorrhizal and AM fungi, tend to be ubiquitous in nature and establish symbiotic associations with most plant species $[13,17,50]$. $\mathrm{P}$ is the most common nutrient from which plants benefit when these associations are established [20,23,51], particularly in acidic soils, where it is expected to be poorly available to plants [47,52]. There was also an observed seasonal fluctuation in tissue K concentrations, a common feature of this nutrient [53,54]. However, the soil treatments did not influence tissue $\mathrm{K}$ concentrations, although in many studies, it has been shown that mycorrhizal fungi can improve K nutrition [19,55].

Tissue Ca levels increased in plants treated not only with mycorrhizal fungi, but also with zeolites, in comparison with the control. The average tissue $\mathrm{Mg}$ concentrations were also lowest in the control and significantly different to those of the myco2 treatment. Since this soil is very acidic $\left(\mathrm{pH}_{\mathrm{H} 2 \mathrm{O}}\right.$ of 4.5$)$, problems would be expected for the nutrition of the plants, even though the cultivar Cobrançosa is well adapted to acidic soils [56]. The levels of leaf Ca $\left(2.5-3.5 \mathrm{~g} \mathrm{~kg}^{-1}\right)$ and $\mathrm{Mg}\left(0.9-1.2 \mathrm{~g} \mathrm{~kg}^{-1}\right)$ were much lower than the respective sufficiency ranges $\left(10-20 \mathrm{~g} \mathrm{~kg}^{-1}\right.$ and $2-6 \mathrm{~g} \mathrm{~kg}^{-1}$, respectively) [45], which highlights these nutrients as important limiting factors for plant growth under such conditions. In spite of higher plant and leaf biomasses in mycorrhizal inoculated plants, as with the other elements, 
no dilution effect was observed for the $\mathrm{Ca}$ and $\mathrm{Mg}$ concentrations and, conversely, their enhanced levels, as in the study of Liu et al. [57], suggest considerable selectivity in the absorption or translocation of the two elements when $\mathrm{Ca}$ and $\mathrm{Mg}$ are at suboptimal levels, probably due to the modulation of nutrient transporters within and among plant organs. In addition, the increased $\mathrm{Ca}$ and $\mathrm{Mg}$ concentrations by the mycorrhizal fungi may occur via two mechanisms. The first is to directly enhance $\mathrm{Ca}$ and $\mathrm{Mg}$ uptake due to the extension of the hyphae network, an effect previously reported in olive trees $[16,20]$. The second is the increased total canopy transpiration, a feature that is supported by stomatal conductance and leaf area data, which hastens the mass flow of these nutrients through the soil to the roots of mycorrhizal plants [57]. On the other hand, zeolites contain Ca and $\mathrm{Mg}$ in their own composition (Table 2), and perhaps this can also justify the differences found for the control. Zeolites have negative charges, as a result of the isomorphic substitutions of $\mathrm{Si}^{4+}$ by $\mathrm{Al}^{3+}$ in the silica framework, and a high ion exchange capacity $[6,8]$, which may also have helped to regulate the supply of $\mathrm{Ca}$ and $\mathrm{Mg}$ to plants. Meanwhile, no significant differences were found between soil treatments in the concentration of micronutrients in the tissues. Although the soil, where nutritional disorders are more likely to appear, is acidic [47] (Havlin et al., 2014), most of the micronutrients analyzed were within, or close to, the sufficiency ranges for the crop. B levels were below the sufficiency range, but they were also not significantly influenced by the soil treatments.

With the exception of the July 2019 leaf gas exchange data, this study reveals, most clearly for zeolites, some positive associations between net photosynthesis and mycorrhizal fungi- and zeolite-induced higher leaf $\mathrm{Ca}$ and $\mathrm{Mg}$ concentrations. In accordance with Wang et al. [58], Ca plays a significant role in photosynthesis, as the photosynthesis-correlated proteins are regulated by $\mathrm{Ca}^{2+}$. The nutrient is involved in stomatal and chloroplast movements, the processes of photochemical reactions and regulating the photosynthetic enzyme activities of $C$ assimilation, as well as the reactive oxygen species balance, protecting photosystems. It is also involved in the regulation of photoprotection, particularly in non-photochemical quenching, a mechanism that protects plants from the adverse effects of high light intensity. In addition, Ridolfi et al. (1996) reported that a severe Ca deficiency slightly increased the darkness stomatal aperture and slowed down stomatal opening during dark-light transitions. These are responses which disturb the plant water and $C$ balance and, thus, water use efficiency. On the other hand, as described by Farhat et al. [59], Mg is required for chlorophyll formation, playing a key role in the structure and photochemical activities of photosystems, photosynthetic electron transport and ribulose-1,5-bisphosphate carboxylase/oxygenase activity. In addition, it is involved in carbohydrate transport from source-to-sink organs, a process that also affects photosynthetic rates.

Foliar fertilization increased the pruning wood, plant height and stem diameter over the control, which identifies soil nutrient availability as a limiting factor for plant growth. Higher leaf area dimensions $\left(97.6 \mathrm{dm}^{2}\right.$ plant $^{-1}$ against $76.8 \mathrm{dm}^{2}$ plant $^{-1}$ in the unfertilized plants that were removed during the last pruning event) and net photosynthetic rates, mainly during 2019, were key determinants in these responses. From a nutritional point of view, leaf sprays only significantly increased the levels of $\mathrm{N}$ and $\mathrm{B}$ in the leaves. One of the foliar fertilizers used contained $12 \% \mathrm{~N}$ and $0.02 \% \mathrm{~B}$, and the other $11 \% \mathrm{~B}$, which justifies the increase in the concentration of these nutrients in plant tissues. It has been previously mentioned that these nutrients were found in the tissues below the sufficiency range, which gives them a particularly relevant role in the performance of plants and justifies the stimulus in plant growth that was observed in response to the application of fertilizers. In previous studies, it has also been shown that $\mathrm{N}$ and $\mathrm{B}$ are the main nutritional constraints in olive trees $[35,46,53]$ and other fruit trees [34,49] grown under rainfed conditions in the region. Thus, the nutritional issue seems to have been relevant to the performance of the trees. $\mathrm{N}$ and B were probably the main limiting factors, although the role of commercial mycorrhizal fungi and zeolites in the supply of these nutrients was reduced. It has been documented that mycorrhiza can increase $\mathrm{N}$ availability under certain conditions. It seems that AM fungi may accelerate decomposition and the acquisition of $\mathrm{N}$ directly from organic matter [60]. Koller et al. [18] hypothesized that AM fungi and protozoa interactively facilitate plant $\mathrm{N}$ acquisition from organic matter. However, these soils are very poor in organic matter (Table 1) and, 
since the beginning of the experiment, the soil was kept free of weeds by tillage, which reduced the entry of fresh organic residues, an indispensable condition for the beneficial effect of mycorrhiza on soil $\mathrm{N}$ availability [18]. There is also no evidence that mycorrhizal fungi or zeolites improve the availability of $\mathrm{B}$ to plants, nor have we found any reference to this possibility from previous studies. Tissue $\mathrm{P}$ levels have increased over time, which is evidence of the positive role of soil microbiology in supplying $\mathrm{P}$ from P-sparse sources ordinarily not available to host plants [61]. Since this soil is very acidic, it is expected that the native microbiology could be efficient in solubilizing and taking up $\mathrm{P}$, which may have obscured the role of the commercial mycorrhizal fungi. Ca and $\mathrm{Mg}$ might also have limited plant growth, given the soil acidity and leaf $\mathrm{Ca}$ and $\mathrm{Mg}$ concentrations far below the sufficiency ranges. Both mycorrhizal fungi and zeolite treatments increased the levels of these nutrients in the leaves. We hypothesize that mycorrhizal fungi may have facilitated nutrient uptake from the hyphae network, as previously mentioned, and that the zeolites contained these nutrients in their own composition and increased the cationic exchange capacity of the soil.

\section{Conclusions}

The commercial mycorrhizal fungi, and to a lesser extent zeolites, increased the growth of the young olive trees, in association with increments, in general, in stomatal conductance, net photosynthetic rate and leaf area dimensions. However, the concentration in plant tissues of most of the essential nutrients, in particular N, P, K and B, did not significantly change with soil treatments, whereas leaf $\mathrm{N}$ and $\mathrm{B}$ concentrations significantly increased with foliar sprays rich in those nutrients. Under experimental conditions that contributed to leaf $\mathrm{Ca}$ and $\mathrm{Mg}$ levels much lower than their respective sufficiency ranges, $\mathrm{Ca}$ and $\mathrm{Mg}$, in turn, increased with soil treatments in comparison with the control, with positive outcomes for plant water status, photosynthetic activity and assimilation area. Thus, it seems that in this very acidic soil and under rainfed conditions, the major benefits for plants from the application of mycorrhizal fungi and zeolites might have been the alleviation of drought stress and the improvement in tissue $\mathrm{Ca}$ and $\mathrm{Mg}$ levels, with these aspects being the reasons why the treated plants grew better than those in the control treatment.

Author Contributions: Field trial installation and maintenance, writing-original draft, J.I.L.; investigation-plant nutrition, writing-review and editing, M.A.; investigation-plant physiology, writing-review and editing, C.B.; field trial installation and maintenance, A.G.; investigation-plant physiology, A.G., E.S. and S.M.; investigation-plant nutrition, S.R.; conceptualization, funding acquisition, supervision, field trial installation and maintenance, writing—review and editing, M.Â.R.; conceptualization, funding acquisition, supervision, field trial installation and maintenance, investigation-plant physiology, writing-review and editing, C.M.C. All authors have read and agreed to the published version of the manuscript.

Funding: This research was funded by the Foundation for Science and Technology (FCT, Portugal) and FEDER under Programme PT2020 for financial support to CIMO (UIDB/00690/2020) and CITAB (UIDB/04033/2020). The research was integrated in the activities of the operational group "Novas práticas em olivais de sequeiro: estratégias de mitigação e adaptação às alterações climáticas", funded by PT2020 and EAFRD (European Agricultural Fund for Rural Development).

Conflicts of Interest: The authors declare that they have no conflict of interest.

\section{References}

1. Rodrigues, M.A.; Ladeira, L.C.; Arrobas, M. Azotobacter-enriched organic manures to increase nitrogen fixation and crop productivity. Eur. J. Agron. 2018, 93, 88-94. [CrossRef]

2. Du Jardin, P.; Xu, L.; Geelen, D. Agricultural functions and action mechanisms of plant biostimulants (PBs): An introduction. In The Chemical Biology of Plant Biostimulants; Geelen, D., Xu, L., Eds.; Wiley: Hoboken, NJ, USA, 2020; pp. 3-29.

3. Guaya, D.; Mendoza, A.; Valderrama, C.; Farran, A.; Sauras-Yera, T.; Cortina, J.L. Use of nutrient-enriched zeolite (NEZ) from urban wastewaters in amended soils: Evaluation of plant availability of mineral elements. Sci. Total. Environ. 2020, 727, 138646. [CrossRef] 
4. Bernardi, A.C.D.C.; Bezerram, M.; Monte, D.M.; Renato, P.; Paiva, P.; Werneck, C.G. Dry matter production and nutrient accumulation after successive crops of lettuce, tomato, rice, and andropogon grass in a substrate with zeolite. Rev. Bras. Ciência 2010, 34, 435-442. [CrossRef]

5. De Smedt, C.; Someus, E.; Spanoghe, P. Potential and actual uses of zeolites in crop protection. Pest Manag. Sci. 2015, 71, 1355-1367. [CrossRef]

6. Litaor, M.I.; Katz, L.; Shenker, M. The influence of compost and zeolite co-addition on the nutrients status and plant growth in intensively cultivated Mediterranean soils. Soil Use Manag. 2017, 33, 72-80. [CrossRef]

7. Villarreal-Núñez, J.E.; Barahona-Amores, L.A.; Castillo-Ortiz, O.A. Efecto de zeolita sobre la eficiencia de fertilizantes nitrogenados en el cultivo de arroz. Agron. Mesoam. 2015, 26, 315. [CrossRef]

8. Palanivell, P.; Ahmed, O.H.; Majid, N.M. Minimizing ammonia volatilization from urea, improving lowland rice (cv. MR219) seed germination, plant growth variables, nutrient uptake, and nutrient recovery using clinoptilolite zeolite. Arch. Agron. Soil Sci. 2016, 62, 708-724. [CrossRef]

9. Ryakhovskaya, N.I.; Gainatulina, V.V. Potato and oat yield in short-cycle crop rotation with zeolite application. Russ. Agric. Sci. 2009, 35, 153-155. [CrossRef]

10. Assimakopoulou, A.; Dimitroulia, D.; Kosmidis, S.; Doula, M.K. Growth, yield and nutrient status of pepper plants grown on a soil substrate with olive mill waste sludge and natural zeolite addition. J. Plant Nutr. 2020, 43, 629-640. [CrossRef]

11. Cooper, J.E.; Scherer, H.W. Nitrogen fixation. In Marschner's Mineral Nutrition of Higher Plants; Marschner, P., Ed.; Elsevier: London, UK, 2012; pp. 389-408.

12. López-Ráez, J.A.; Pozo, M.J. Chemical signalling in the arbuscular mycorrhizal symbiosis: Biotechnological applications. In Symbiotic Endophytes; Aroca, R., Ed.; Springer: Berlin/Heidelberg, Germany, 2013; pp. 215-232.

13. Lanfranco, L.; Bonfante, P.; Genre, A. The mutualistic interaction between plants and arbuscular mycorrhizal fungi. Microbiol. Spectr. 2016, 4, 1-20. [CrossRef]

14. Miransari, M. Arbuscular mycorrhizal fungi and uptake of nutrients. In Symbiotic Endophytes; Aroca, R., Ed.; Springer: Berlin/Heidelberg, Germany, 2013; pp. 253-270.

15. Hu, J.; Lin, X.; Wang, J.; Dai, J.; Cui, X.; Chen, R.; Zhang, J. Arbuscular mycorrhizal fungus enhances crop yield and P-uptake of maize (Zea mays L.): A field case study on a sandy loam soil as affected by long-term P-deficiency fertilization. Soil Biol. Biochem. 2009, 41, 2460-2465. [CrossRef]

16. Mechri, B.; Attia, F.; Tekaya, M.; Cheheb, H.; Hammami, M. Colonization of olive trees (Olea europaea L.) with the arbuscular mycorrhizal fungus Glomus sp. modified the glycolipids biosynthesis and resulted in accumulation of unsaturated fatty acids. J. Plant Physiol. 2014, 171, 1217-1220. [CrossRef]

17. Ortas, I.; Bykova, A. The Effect of Mycorrhiza Inoculation and Phosphorus Application on Phosphorus Efficiency of Wheat Plants. Commun. Soil Sci. Plant Anal. 2018, 49, 1199-1207. [CrossRef]

18. Koller, R.; Rodriguez, A.; Robin, C.; Scheu, S.; Bonkowski, M. Protozoa enhance foraging efficiency of arbuscular mycorrhizal fungi for mineral nitrogen from organic matter in soil to the benefit of host plants. New Phytol. 2013, 199, 203-211. [CrossRef]

19. Garcia, K.; Zimmermann, S.D. The role of mycorrhizal associations in plant potassium nutrition. Front. Plant Sci. 2014, 5, 337. [CrossRef]

20. Tekaya, M.; Mechri, B.; Mbarki, N.; Cheheb, H.; Hammami, M.; Attia, F. Arbuscular mycorrhizal fungus Rhizophagus irregularis influences key physiological parameters of olive trees (Olea europaea L.) and mineral nutrient profile. Photosynthetica 2017, 55, 308-316. [CrossRef]

21. Calvo-Polanco, M.; Sánchez-Romera, B.; Aroca, R. Arbuscular mycorrhizal fungi and the tolerance of plants to drought and salinity. In Symbiotic Endophytes; Aroca, R., Ed.; Springer: Berlin/Heidelberg, Germany, 2013; pp. 271-288.

22. Ouledali, S.; Ennajeh, M.; Zrig, A.; Gianinazzi, S.; Khemira, H. Estimating the contribution of arbuscular mycorrhizal fungi to drought tolerance of potted olive trees (Olea europaea). Acta Physiol. Plant. 2018, 40, 81. [CrossRef]

23. Bati, C.B.; Santilli, E.; Lombardo, L. Effect of arbuscular mycorrhizal fungi on growth and on micronutrient and macronutrient uptake and allocation in olive plantlets growing under high total Mn levels. Mycorrhiza 2015, 25, 97-108. [CrossRef]

24. Zhan, F.; Li, B.; Jiang, M.; Yue, X.; He, Y.; Xia, Y.-S.; Wang, Y. Arbuscular mycorrhizal fungi enhance antioxidant defence in the leaves and the retention of heavy metals in the roots of maize. Environ. Sci. Pollut. Res. 2018, 25, 24338-24347. [CrossRef] 
25. Berdeni, D.; Cotton, T.E.A.; Daniell, T.J.; Bidartondo, M.I.; Cameron, D.D.; Evans, K.L. The Effects of Arbuscular Mycorrhizal Fungal Colonisation on Nutrient Status, Growth, Productivity, and Canker Resistance of Apple (Malus pumila). Front. Microbiol. 2018, 9, 1461. [CrossRef]

26. Godbold, D.L.; Hoosbeek, M.R.; Lukac, M.; Cotrufo, M.F.; Janssens, I.A.; Ceulemans, R.; Polle, A.; Velthorst, E.J.; Scarascia-Mugnozza, G.; De Angelis, P.; et al. Mycorrhizal Hyphal Turnover as a Dominant Process for Carbon Input into Soil Organic Matter. Plant Soil 2006, 281, 15-24. [CrossRef]

27. Högberg, M.N.; Skyllberg, U.; Högberg, P.; Knicker, H. Does ectomycorrhiza have a universal key role in the formation of soil organic matter in boreal forests? Soil Biol. Biochem. 2020, 140, 107635. [CrossRef]

28. Rodrigues, M.A.; Piroli, L.B.; Forcelini, D.; Raimundo, S.; Domingues, L.S.; Cassol, L.C.; Correia, C.M.; Arrobas, M. Use of commercial mycorrhizal fungi in stress-free growing conditions of potted olive cuttings. Sci. Hortic. 2021, 275, 109712. [CrossRef]

29. Bacelar, E.A.; Moutinho-Pereira, J.M.; Gonçalves, B.C.; Ferreira, H.F.; Correia, C.M. Changes in growth, gas exchange, xylem hydrualic properties and water use efficiency of three olive cultivars under contrasting water availability regimes. Environ. Exp. Bot. 2007, 60, 183-192. [CrossRef]

30. Brito, C.; Dinis, L.-T.; Luzio, A.; Silva, E.; Gonçalves, A.; Meijón, M.; Escandón, M.; Arrobas, M.; Rodrigues, M.A.; Moutinho-Pereira, J.; et al. Kaolin and salicylic acid alleviate summer stress in rainfed olive orchards by modulation of distinct physiological and biochemical response. Sci. Hortic. 2019, 246, 201-211. [CrossRef]

31. Brito, C.; Dinis, L.-T.; Silva, E.; Gonçalves, A.; Matos, C.; Rodrigues, M.A.; Moutinho-Pereira, J.; Barros, A.; Correia, C. Kaolin and salicylic acid foliar application modulate yield, quality and phytochemical composition of olive pulp and oil from rainfed trees. Sci. Hortic. 2018, 237, 176-183. [CrossRef]

32. Ferreira, I.Q.; Arrobas, M.; Claro, A.M.; Rodrigues, M.A. Soil management in rainfed olive orchards may result in conflicting effects on olive production and soil fertility. Span. J. Agric. Res. 2013, 11, 472. [CrossRef]

33. Rodrigues, M.A.; Dimande, P.; Pereira, E.; Ferreira, I.Q.; Freitas, S.; Correia, C.M.; Moutinho-Pereira, J.; Arrobas, M. Early-maturing annual legumes: An option for cover cropping in rainfed olive orchards. Nutr. Cycl. Agroecosyst. 2015, 103, 153-166. [CrossRef]

34. Arrobas, M.; Santos, D.; Ribeiro, A.; Pereira, E.; Rodrigues, M.A. Soil and foliar nitrogen and boron fertilization of almond trees grown under rainfed conditions. Eur. J. Agron. 2019, 106, 39-48. [CrossRef]

35. Ferreira, I.Q.; Rodrigues, M.A.; Arrobas, M. Soil and foliar applied boron in olive: Tree crop growth and yield, and boron remobilization within plant tissues. Span. J. Agric. Res. 2019, 17, e0901. [CrossRef]

36. Von Caemmerer, S.; Farquhar, G.D. Some relationships between the biochemistry of photosynthesis and the gas exchange of leaves. Planta 1981, 153, 376-387. [CrossRef]

37. Van Reeuwijk, L.P. Procedures for Soil Analysis, 6th ed.; Technical Paper 9; ISRIC, FAO: Wageningen, The Netherlands, 2002.

38. Balbino, L.R. La Méthode Egner-Riehm et la Détermination du Phosfore et du Potassium «assimilável» des sols du Portugal. II Col. Medit Cont. Fert. Plantas Cultivadas; Facultad de Ciencias: Sevilla, Spain, 1968; pp. 55-65.

39. Jones, J.B., Jr. Laboratory Guide for Conducting Soil Tests and Plant Analysis; CRC Press: Boca Raton, FL, USA, 2001.

40. Temminghoff, E.E.J.M.; Houba, V.G. Plant Analysis Orocedures, 2nd ed.; Klwuwer Academic Publishers: AA Dordrecht, The Netherlands, 2004.

41. Rapoport, H.L. Botânica e Morfología. In El Cultivo del Olivo, 7th ed.; Barranco, D., Fernández-Escobar, R., Rallo, L., Eds.; Mundi-Prensa: Madrid, Spain, 2017; pp. 35-64.

42. Shao, Y.D.; Zhang, D.J.; Hu, X.C.; Wu, Q.S.; Jiang, C.J.; Xia, T.J.; Gao, X.B.; Kuča, K. Mycorrhiza-induced changes in root growth and nutrient absorption of tea plants. Plant Soil Environ. 2018, 64, 283-289. [CrossRef]

43. Chandrasekaran, M.; Chanratana, M.; Kim, K.; Seshadri, S.; Sa, T. Impact of Arbuscular Mycorrhizal Fungi on Photosynthesis, Water Status, and Gas Exchange of Plants Under Salt Stress-A Meta-Analysis. Front. Plant Sci. 2019, 10, 457. [CrossRef]

44. Flexas, J.; Medrano, H. Drought inhibition of photosynthesis in C3 plants: Stomatal and non-stomatal limitations revisited. Ann. Bot. 2002, 89, 183-189. [CrossRef]

45. Bryson, G.; Mills, H.; Sasseville, D.; Jones, J.B., Jr.; Barker, A. Plant Analysis Handbook III: A Guide to Sampling, Preparation, Analysis and Interpretation for Agronomic and Horticultural Crops; Micro-Macro Publishing: Athens, GA, USA, 2014. 
46. Ferreira, I.Q.; Arrobas, M.; Moutinho-Pereira, J.M.; Correia, C.M.; Rodrigues, M.A. The effect of nitrogen applications on the growth of young olive trees and nitrogen use efficiency. Turk. J. Agric. For. 2020, 44, 278-289. [CrossRef]

47. Havlin, J.L.; Tisdale, S.L.; Nelson, W.L.; Beaton, J.D. Soil Fertility and Fertilizers, an Introduction to Nutrient Management, 8th ed.; Pearson: Boston, MA, USA, 2014.

48. Jarrell, W.M.; Beverly, R.B. The Dilution Effect in Plant Nutrition Studies. Adv. Agron. 1981, 34, $197-224$. [CrossRef]

49. Arrobas, M.; Afonso, S.; Rodrigues, M.A. Diagnosing the nutritional condition of chestnut groves by soil and leaf analyses. Sci. Hortic. 2018, 228, 113-121. [CrossRef]

50. Ågren, G.I.A.; Hyvönen, R.; Baskaran, P. Ectomycorrhiza, Friend or Foe? Ecosystems 2019, 22, 1561-1572. [CrossRef]

51. Marschner, P.; Solaiman, Z.; Rengel, Z. Growth, phosphorus uptake, and rhizosphere microbial-community composition of a phosphorus-efficient wheat cultivar in soils differing in pH. J. Plant Nutr. Soil Sci. 2005, 168, 343-351. [CrossRef]

52. Chaney, K. Phosphate Fertilizers (Cap. 6). In Ullmann's Agrochemicals 1; Wiley-VCH, Verlag GmbH \& Co. KGaA: Weinheim, Germany, 2007.

53. Rodrigues, M.A.; Pavão, F.; Lopes, J.I.; Gomes, V.; Arrobas, M.; Moutinho-Pereira, J.; Ruivo, S.; Cabanas, J.E.; Correia, C.M. Olive Yields and Tree Nutritional Status during a Four-Year Period without Nitrogen and Boron Fertilization. Commun. Soil Sci. Plant Anal. 2011, 42, 803-814. [CrossRef]

54. Ferreira, I.Q.; Arrobas, M.; Moutinho-Pereira, J.M.; Correia, C.; Rodrigues, M.A. Olive response to potassium applications under different water regimes and cultivars. Nutr. Cycl. Agroecosyst. 2018, 112, 387-401. [CrossRef]

55. Dag, A.; Yermiyahu, U.; Ben-Gal, A.; Zipori, I.; Kapulnik, Y. Nursery and post-transplant field response of olive trees to arbuscular mycorrhizal fungi in an arid region. Crop. Pasture Sci. 2009, 60, 427-433. [CrossRef]

56. Arrobas, M.; Moutinho-Pereira, J. Fertilização do olival. In Manual da Safra e Contra Safra do Olival; Rodrigues, M.A., Correia, C., Eds.; Instituto Politécnico de Bragança: Bragança, Portugal, 2009; pp. 21-39. ISBN 978-972-745-103-6.

57. Liu, A.; Hamel, C.; Elmi, A.; Costa, C.; Ma, B.; Smith, D.L. Concentrations of K, Ca and Mg in maize colonized by arbuscular mycorrhizal fungi under field conditions. Can. J. Soil Sci. 2002, 82, 271-278. [CrossRef]

58. Wang, Q.; Yang, S.; Wan, S.; Li, X. The Significance of Calcium in Photosynthesis. Int. J. Mol. Sci. 2019, 20, 1353. [CrossRef]

59. Farhat, N.; Elkhouni, A.; Zorrig, W.; Smaoui, A.; Abdelly, C.; Rabhi, M. Effects of magnesium deficiency on photosynthesis and carbohydrate partitioning. Acta Physiol. Plant. 2016, 38. [CrossRef]

60. Hodge, A.; Campbell, C.D.; Fitter, A.H. An arbuscular mycorrhizal fungus accelerates decomposition and acquires nitrogen directly from organic material. Nature 2001, 413, 297-299. [CrossRef]

61. Valentine, A.J.; Mortimer, P.E.; Kleinert, A.; Kang, Y.; Benedito, V.A. Carbon metabolism and costs of arbuscular mycorrhizal associations to host roots. In Symbiotic Endophytes; Aroca, R., Ed.; Springer: Berlin/Heidelberg, Germany, 2013; pp. 233-252.

Publisher's Note: MDPI stays neutral with regard to jurisdictional claims in published maps and institutional affiliations.

(C) 2020 by the authors. Licensee MDPI, Basel, Switzerland. This article is an open access article distributed under the terms and conditions of the Creative Commons Attribution (CC BY) license (http://creativecommons.org/licenses/by/4.0/). 